\title{
TRG VATROSLAVA LISINSKOG U OSJEČKOJ TVRĐI - POVIJESNI I PROSTORNI RAZVOJ
}

\section{Sanja Lončar-Vicković}

Sveučilište Josipa Jurja Strossmayera u Osijeku, Građevinski fakultet Osijek, prof.dr.sc.

Željka Jurković

Sveučilište Josipa Jurja Strossmayera u Osijeku, Građevinski fakultet Osijek

Dina Stober

Sveučilište Josipa Jurja Strossmayera u Osijeku, Građevinski fakultet Osijek, dr.sc.

Sažetak: Autorice u članku donose prikaz povijesnog i prostornog razvitka Trga Vatroslava Lisinskog u osječkoj Tvrđi, počevši od njegovog formiranja do danas. Na osnovi istraživanja kartografskih prikaza i ostalih dostupnih izvora, prezentirana je detaljna geneza razvoja prostora Trga te mijena njegovih funkcija i naziva. Članak se zaključuje vrjednovanjem postojećeg stanja Trga Vatroslava Lisinskog te njegovih potencijala obnove i regeneracije.

Ključne riječi: Osijek, Tvrđa, Trg Vatroslava Lisinskog, povijest, prostor

\section{VATROSLAV LISINSKI SQUARE IN OSIJEK'S TVRĐA - HISTORICAL AND SPATIAL DEVELOPMENT}

\begin{abstract}
The paper describes historical and spatial development of Vatroslav Lisinski Square in Tvrđa, Osijek, from its formative beginning to nowadays. Researching historical maps and other available data, a detailed genesis of square's functions and historical changes is presented. The article concludes with the evaluation of the present condition of Vatroslav Lisinski Square and its potentials for future reconstruction and regeneration.
\end{abstract}

Key words: Osijek, Tvrđa, Vatroslav Lisinski Square, history, space 


\section{Uvod}

Prostor Trga Vatroslava Lisinskog nalazi se u sjevernom dijelu osječke Tvrđe, u blizini rijeke Drave, a zauzima površinu od $6880 \mathrm{~m}^{2}$. Specifičnost Trga unutar dovršene urbanističke cjeline Tvrđe je njegova višestoljetna sadržajna nedefiniranost, parterna neuređenost i odsustvo urbanog mobilijara. lako se formalno naziva "trgom“, radi se o plohi za koju do sada nema pokazatelja da je u prošlosti predstavljala značajan gradski prostor okupljanja i komuniciranja, već se radi o prostoru koji je povremeno bio popunjen pomoćnim zgradama ili hortikulturnim uređenjem, a sve unutar definirane i izgrađene perimetarne strukture okolnih zgrada. Trg se danas koristi kao neuređena prometna parkirališna površina (slika 1).

Pokusna arheološka istraživanja na površini od $625 \mathrm{~m}^{2}$ u sjeveroistočnom dijelu Trga Vatroslava Lisinskog, zapadno od franjevačkog samostana, proveo je tim Arheološkog muzeja u Osijeku od 2010. do 2011. godine (slika 2). Istraživanje je započelo na temelju pretpostavke da je na toj lokaciji bila smještena kasnosrednjovjekovna utvrda plemićke obitelji Korođ. Rezultati arheoloških istraživanja pokazali su slojevitost prostora Trga koja je potvrdila frekventnost lokacije kao mjesta najpovoljnijeg prijelaza preko rijeke Drave. Najviše tragova je iz doba Austro-Ugarske (tzv. austrijski horizont), zatim postoje tragovi iz turskog i srednjovjekovnog razdoblja, dok su najstariji slojevi iz kasnog brončanog, mlađeg željeznog i rimskog doba.

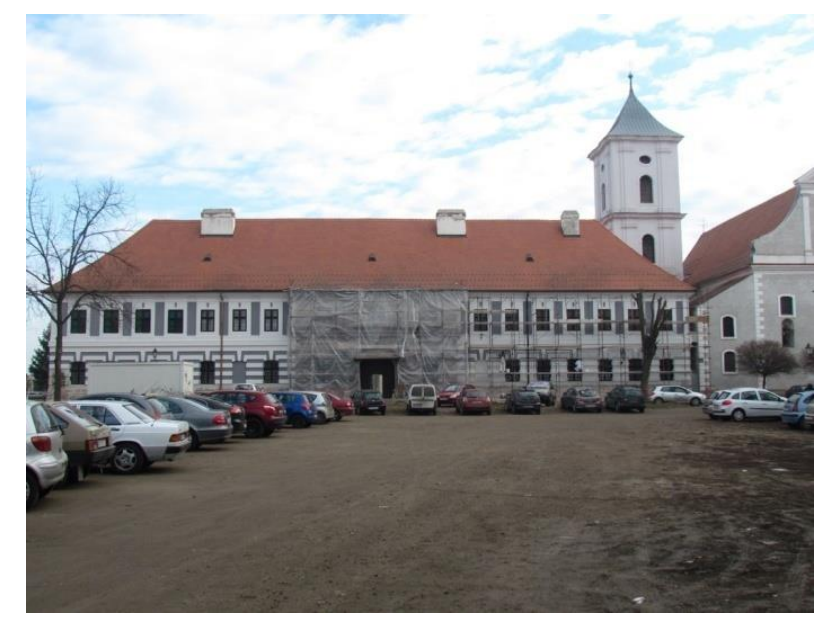

Slika 1 - Trg Vatroslava Lisinskog danas

Svrha članka je temeljem istraživanja povijesne građe i dokumentacijskih izvora dati sustavan prikaz nastanka i razvitka Trga. Na kraju članka istraženi su današnji urbanistički, arhitektonski i socijalni potencijali Trga kao javnog gradskog prostora u kontekstu javnih prostora Tvrđe.

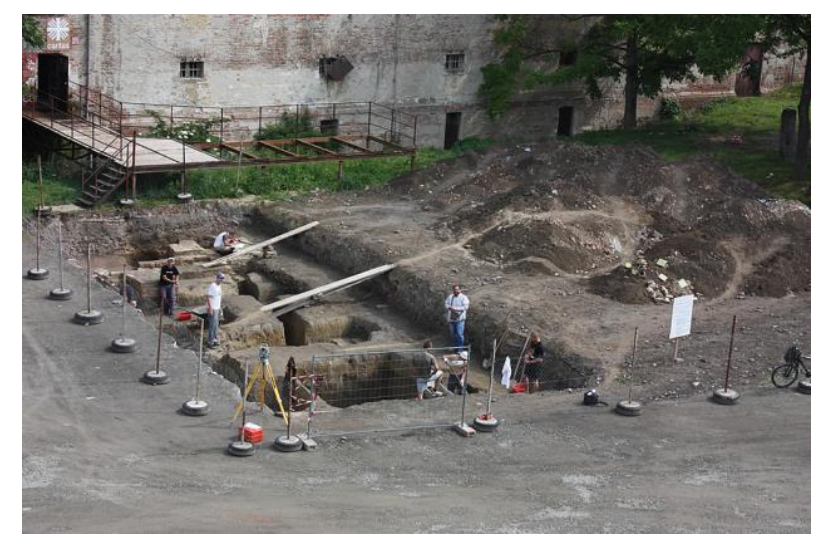

Slika 2 - Pokusna arheološka istraživanja na Trgu Vatroslava Lisinskog, od 2010. do 2011. godine 


\section{Povijesno-prostorni razvoj Tvrđe}

Prostor današnje Tvrđe počinje se naseljavati u 10. stoljeću, kada Slaveni na tom mjestu osnivaju grad Osijek. Srednjovjekovnim gradom 14.-tog i 15.-tog stoljeća vlada obitelj Korođ. Nakon velikog turskog pohoda, Osijek predaje ključeve osvajačima 1526. godine, nakon čega počinje sistematska gradnja dva periferna lanca bedema. U daljnjim desetljećima turski Osijek raste u mreži ortogonalno postavljenih ulica, okomitih na bedeme, što ukazuje na očuvanje urbanizma srednjovjekovne prethodnice. Na početku 17. stoljeća Osijek, povoljno strateški lociran, uz postojeću funkciju vojne utvrde postaje i važno prometno i trgovačko središte.

Nakon ulaska austrijske vojske u Osijek 1687. Godine, počinje novo utvrđivanje lokacije Tvrđe. Nasljedstvo turskog obrambenog inženjeringa se djelomično zadržava te planirani bastioni s ravelinima, kavalirima i kordonima slijede prethodne turske fortifikacije. Graditeljski fond se mijenja zbog vojnih graditeljskih pravila Austro-Ugarske i tkivo Tvrđe popunjava se zgradama od pečene opeke, a trase ulica se zadržavaju [1]. Fortifikacijska direkcija egzistirala je u Tvrđi od 1710. godine, a izgradnja Tvrđe kakvu danas poznajemo počinje 1712. godine pod vodstvom maršala J. S. Beckersa. Do 1719. godine tvrđava je većinom završena, no gradnja je nastavljena i tijekom prve polovice 18. stoljeća. U 19. stoljeću javlja se potreba za povezivanjem istočnog i zapadnog dijela grada koja, uz ekonomske razloge, uzrokuje razgradnju sjeverozapadnih bedema 70 -tih godina 19. stoljeća. U istom razdoblju dolazi do gubitka vojne namjene Tvrđe, gospodarske stagnacije te novih razvojnih smjernica grada. Bedemi postaju barijera te in se ne valorizira kao vrijedan prostorni element već kao potencijalni resurs građevinskog materijala, što je u skladu s Regulatornom osnovom iz 1883. godine koja proklamira ostvarivanje urbanog jedinstva, tj. povezanost svih dijelova grada. Stanje u Europi početkom 20. stoljeća i I. svjetski rat odlažu planove o rušenju utvrđenja do 1923. godine kada se rušenje nastavlja, a ubrzava ga i trasiranje električnog tramvaja. Nakon rušenja bedema, južno od Tvrđe sagrađena je glavna gradska cestovna longitudinala u smjeru istok-zapad koja uključuje i tramvajski promet. Autori Krajnik i Obad-Šćitaroci [2] ističu posebnost kašnjenja preobrazbe fortifikacijskog prstena u slučaju Tvrđe u usporedbi s analognim primjerima hrvatskog i europskog prostora, nalazeći prednost kasnije reakcije u kvalitetno izgrađenom oblikovanom sklopu javnih gradskih prostora i zgrada javne namjene. Nakon toga, do danas, izgrađena struktura Tvrđe i okolnog prostora nije se mijenjala.

\section{Geneza razvoja Trga Vatroslava Lisinskog}

Geneza povijesnog razvoja Trga istražena je temeljem rezultata arheoloških istraživanja te analize karata i planova Tvrđe. Korištena je kartografska i studijska građa Državnog arhiva u Osijeku, Konzervatorskog odjela Osijek, Restauratorskog odjela u Osijeku te Gradske i sveučilišne knjižnice Osijek. Razvoj prostora Trga istražen je i u dostupnoj literaturi autora čiji je istraživački fokus prostor Tvrđe. Prikaz nastanka i razvoja Trga Vatroslava Lisinskog istražen je i prezentiran po karakterističnim povijesnim razdobljima.

\subsection{Razdoblje od prapovijesti do osnutka Tvrđe}

Prapovijesnim nalazima iz mlađeg željeznog doba pripadaju jame s keramičkim ulomcima i ostatci manjih koničnih posudica za lijevanje metala iz kulture Skordiska, naselja čije se središte nalazilo u Donjem gradu. Istom razdoblju pripadaju ulomci staklenih (perle oblikovane kao ljudsko lice) i metalnih predmeta iz 3. do 1. stoljeća prije nove ere. Iz vremena 6 . i 5 . stoljeća prije Krista nađena je brončana fibula i još neki manji metalni nalazi koji pokazuju kontinuitet naseljavanja na ovoj lokaciji.

Rimsko razdoblje može se prepoznati u ostatcima poluzemunica s nabijenim podnicama i stupovima i spremnica. Dijelu rimske infrastrukture pripadaju i jarci te ukopi stupova koji bi mogli naznačiti ostatke nadzemnih građevina te ulomci opeka i tegula kao građevnog materijala. Nalazi dokumentiraju postojanje kasnorimskog ruralnog naselja na rubu velike urbane cjeline Murse. Također, ostaci dubokog obrambenog jarka (fossa) naznačuju postojanje rimskog vojnog logora zapadno od Murse. 
Ostaci srednjovjekovnog Osijeka ne potvrđuju postojanje kaštela obitelji Korođ na lokaciji Trga, već se pretpostavlja da se on nalazio nešto istočnije. Na Trgu su nađeni tragovi kasnosrednjovjekovnih drvenih objekata (kuća, spremišta ili ograda) te keramike iz razvijenog srednjeg vijeka.

Iz razdoblja turskog Osijeka nađeni su ostatci dviju peći i nekoliko manjih jama koje ukazuju na postojanje dijela naselja; ovaj nalaz negira pretpostavljenu raniju srednjovjekovnu rezidencijalnu i sakralnu funkciju ovog prostora (slika 3). Ostatci većih građevina nisu pronađeni, što ukazuje na činjenicu da oni ovdje nisu ni postojali, osim ambara i spremišta za topove [3].

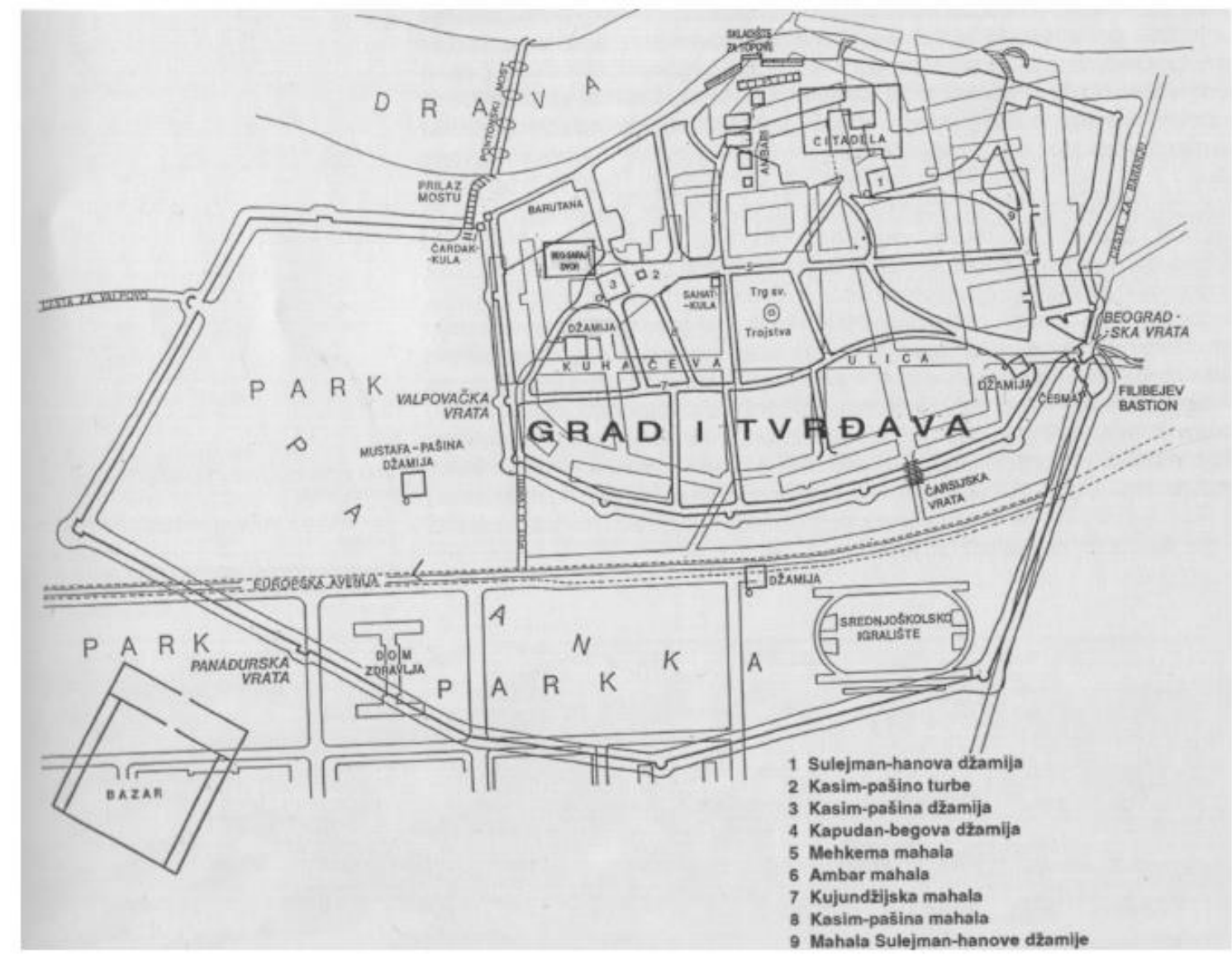

Slika 3 - Rektifikacija plana turskog Osijeka iz 1688. godine

\subsection{Razdoblje od osnutka Tvrđe do 1918. godine}

Današnji prostor Trga Vatroslava Lisinskog definiran je u doba izgradnje Tvrđe kao područje omeđeno velikim i značajnim zgradama različite tipologije. Na nekoliko karata iz doba Austro-Ugarske, okolne zgrade su namjenom utvrđene kao:

a) KK Verpflegs Baeckerei ili Verpfleg Magazin na sjevernoj strani Trga - 1714. godina

b) Oberes Zeughaus ili Oberes Artilleriezeughaus na istočnoj strani Trga, na mjestu gdje se danas nalazi franjevački samostan - 1714. godina

c) Generalat Haus, General Cassarne ili General kaserne na jugu - 1726. godina, dogradnja 2. kata 1765. godina

d) Artill. Depot (artiljerijsko skladište) ili Proviant Kaserne na zapadu - do 1750. godine.

Izvještajni plan inženjera Heissea o izvedenim radovima u Tvrđi iz 1732. godine svjedoči o formiranju prostora Trga u kontekstu gradnje Eugenovog bastiona, Opskrbničke vojarne te vojne pekare i skladišta. Najvažniji arheološki nalaz na Trgu, nađen u kasnosrednjovjekovnom sloju, predstavlja ostatke temelja (ukopi 
temelja) zgrade koja se pojavljuje na planovima Tvrđe početkom 18. stoljeća (1712. i 1715. godine) i za koju se prepoznaju dvije graditeljske faze. Zgrada je najvjerojatnije bila skladište pravokutnog tlocrtnog oblika sa središnjim dvorištem, smještena u istočnom dijelu Trga, zapadno od franjevačkog samostana. $U$ povijesnim je prikazima zabilježen požar skladišta na ovoj lokaciji 1751. godine, kada je skladište do temelja izgorjelo, a njegovu je funkciju preuzela Opskrbnička vojarna (Proviant Kaserne). Iz povijesnih karata ovog razdoblja vidljivo je da Trg Vatroslava Lisinskog nema prostornu važnost koju imaju druga dva tvrđavska trga - Trg Svetoga Trojstva i Križanićev trg. Ova pretpostavka se dokazuje činjenicom da Trg Vatroslava Lisinskog nije imenovan na kartama na kojima su ostala dva glavna trga imenovana, ili je opisno imenovan kao na karti iz 1811. godine na kojoj je nazvan „Platz des abgebrenten Proviant Magazins" - trg / mjesto provijantnog skladišta koje je izgorjelo 1751. godine. Također, za Trg Svetoga Trojstva i Križanićev trg postoje u Državnom arhivu u Osijeku detaljiji nacrti koji se za Trg Vatroslava Lisinskog ne mogu naći.

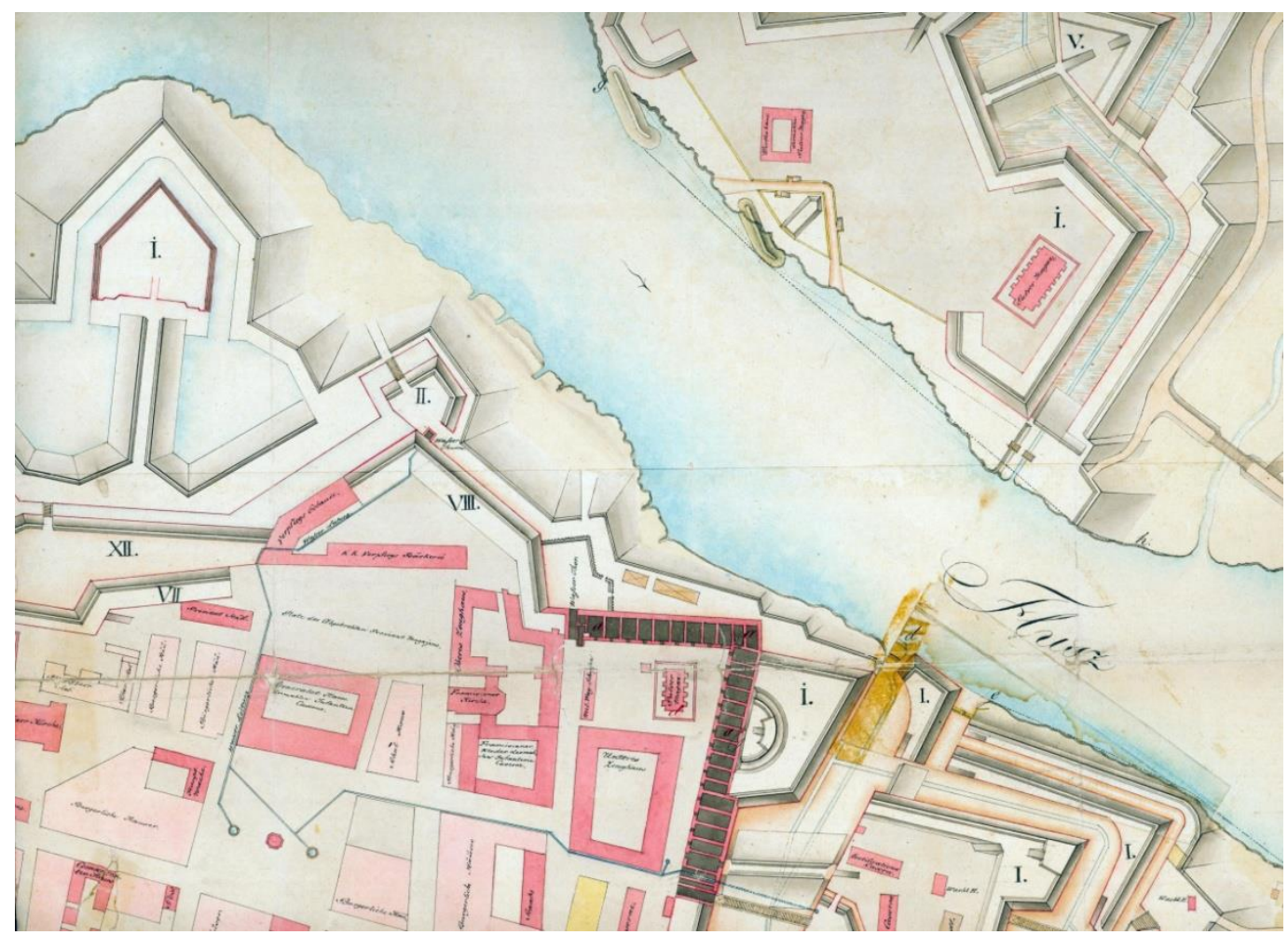

Slika 4 - Dio karte Tvrđe iz 1811. godine

Na karti iz 1811. godine (slika 4) prikazuje se položaj i naziv Trga Vatroslava Lisinskog u sjevernom dijelu Tvrđe kao Platz des abgebrenten Proviant Magazins. Na nekoliko daljnjih karata Tvrđe vidljivi su nasadi visokog zelenila na Trgu, ponekad u obliku dvostrukog drvoreda, a ponekad u obliku jednostrukog ili nepravilnog rasporeda (slika 5). Najmlađa takva karta je Plan der Festung Esseg iz 1861. godine (slika 6), gdje je vidljiv dvostruki drvored po obodu Trga, dok mu je zapadna strana definirana promjenom visine terena. Na karti Osijeka iz 1893. godine Trg je prvi puta nazvan imenom Promenade, dok na karti iz 1908. godine, koja prikazuje raspored vodovodne mreže u Tvrđi, Trg nije imenovan. Na Regulatornoj osnovi Osijeka iz 1912. godine Trg je nazvan Šetalištem (slika 7). 


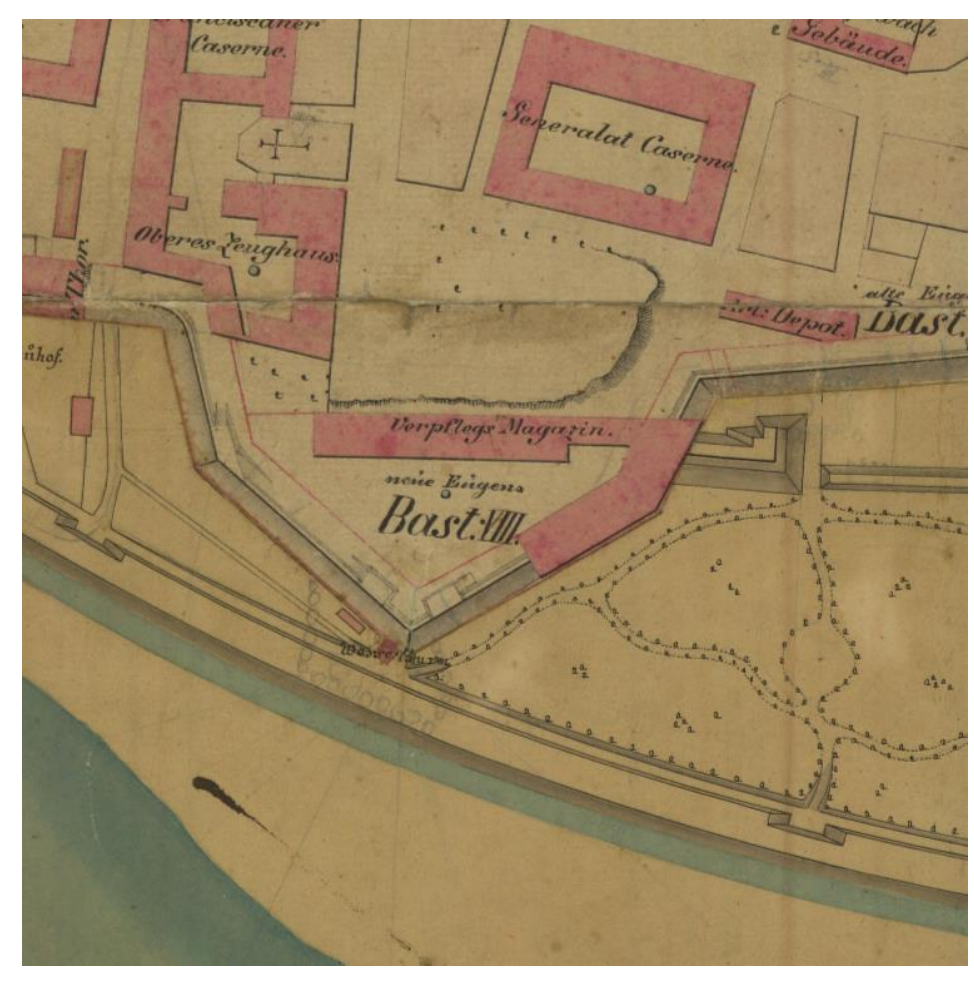

Slika 5 - Dio karte Tvrđe iz 1844. godine s jednostrukim, nepravilnim drvoredom

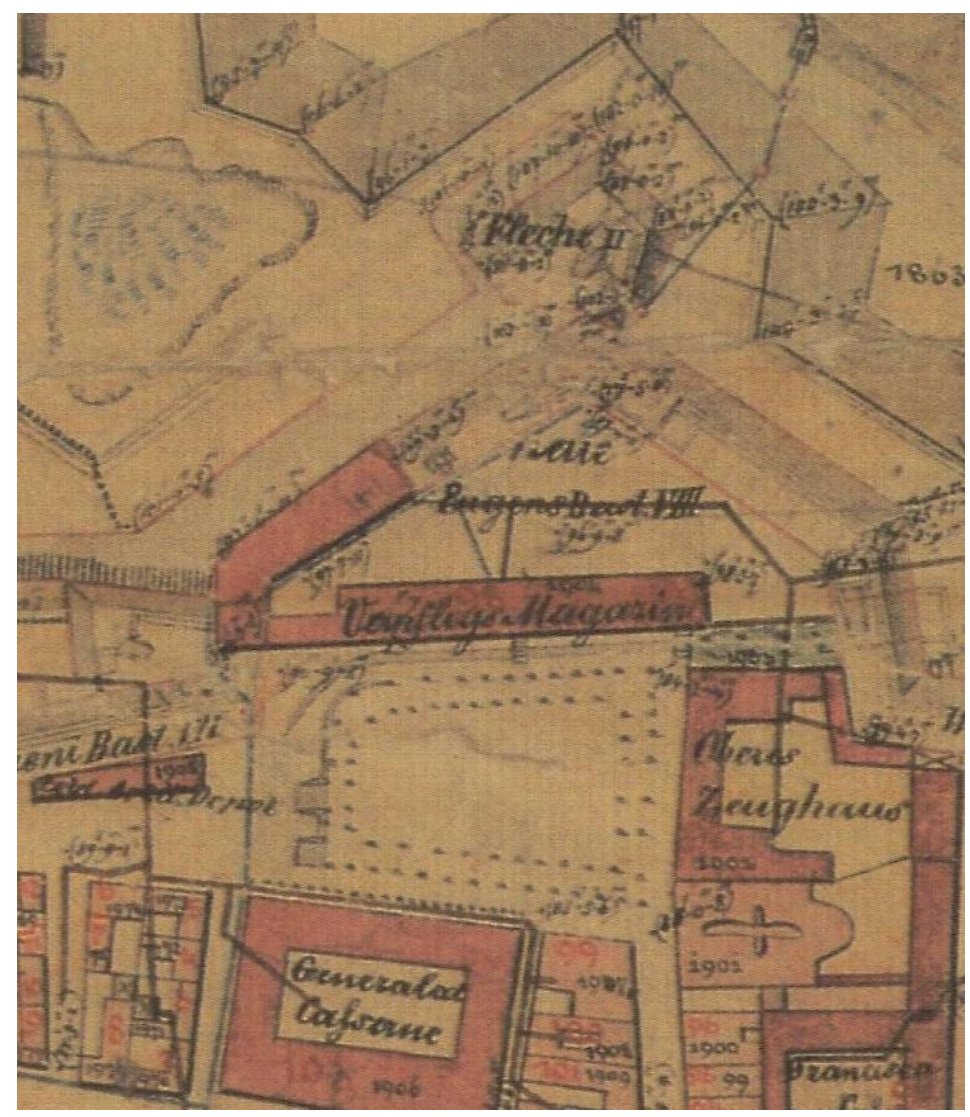

Slika 6 - Dio karte Tvrđe iz 1861. godine s dvostrukim drvoredom 


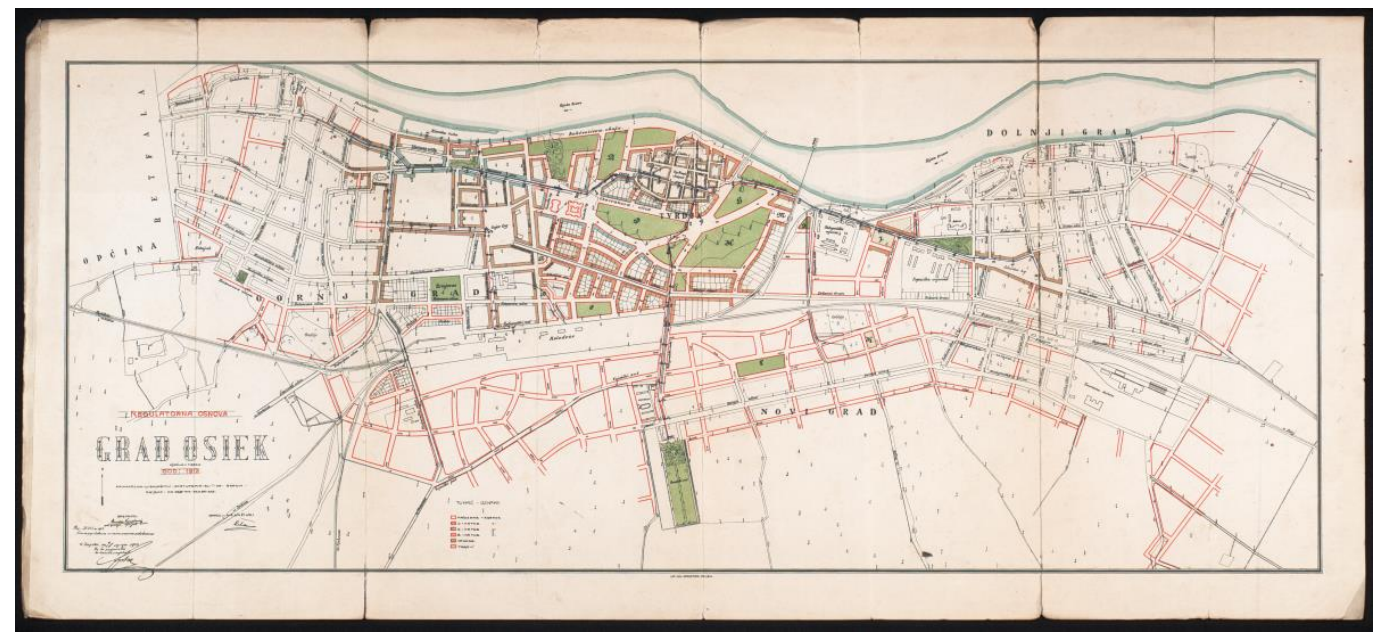

Slika 7 - Regulatorna osnova Osijeka iz 1912. godine

\subsection{Razdoblje stare Jugoslavije - od 1918. do 1945. godine}

Na kartama iz razdoblja između I. i II. svjetskog rata Trg Vatroslava Lisinskog naziva se Franjevački trg, s dodatnim imenom u zagradi - "Šetalište". I na ovim kartama se pojavljuje obodni dvostruki drvored, a na čak dvije karte - jednoj iz 1932. godine - prisutan je i prikaz zgrade na zapadnoj strani Trga. Ta zgrada, na karti iz razdoblja od 1938. do 1941. godine, ima i broj katastarske čestice, budući da je tada Trg bio podijeljen na tri katastarske čestice - čestica 2403/1 je površina nekadašnje zgrade na zapadnoj strani Trga, čestica 2403/2 je ulica između zgrade General-vojarne i Trga, a čestica 2403/3 pripada otvorenom ostatku prostora Trga (slika 8).

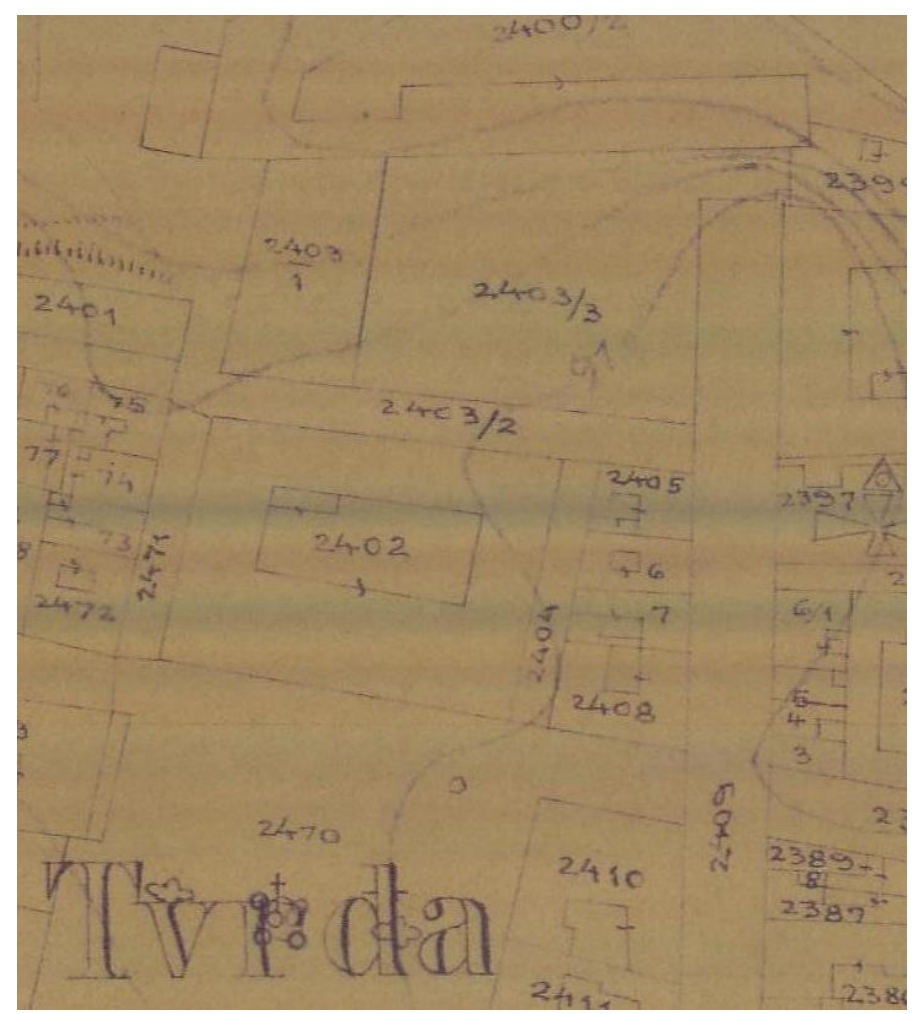




\section{Slika 8 - Dio karte Tvrđe s kraja tridesetih godina 20. Stoljeća, s prikazom tri katastarske čestice na Trgu 3.4 Razdoblje poslije 1945. godine do danas \\ Vatroslava Lisinskog}

Na karti Osijeka iz 1945. godine Trg se nalazi u Rajonu II - Tvrđa i nazvan je imenom narodnog heroja Svetozara Rittiga [4]. Konačan naziv po hrvatskom skladatelju Vatroslavu Lisinskom Trg dobiva 1952. godine.

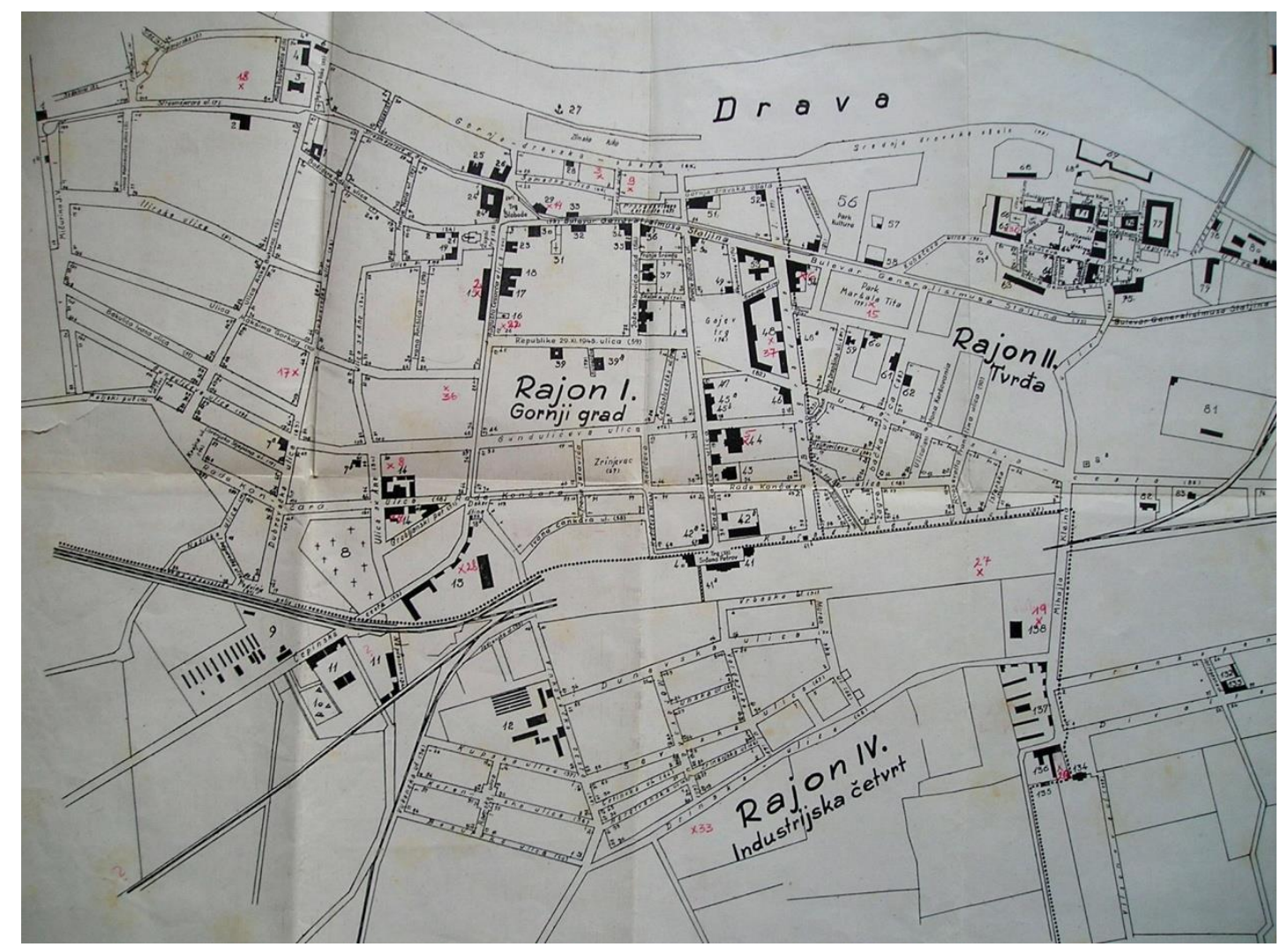

Slika 9 - Dio karte Osijeka iz 1945. godine

\section{Potencijal prostora Trga Vatroslava Lisinskog}

Preporuka ICOMOS-a iz 1976. godine utvrđuje da svako povijesno područje i njegova okolina trebaju biti sagledani kao jedinstvena cjelina, čija ravnoteža i posebnost ovise o kompoziciji dijelova od kojih su sastavljeni i koji uključuju zgrade te prostornu organizaciju i njihovu okolinu [5]. Povelja ICOMOS-a za konzervaciju povijesnih gradova i urbanih područja iz 1987. godine donosi vrjednovanje raznolikosti urbanih povijesnih prostora čija je pojava rezultat dugotrajnih procesa i koja odražavaju namjere i potrebe raznih povijesnih razdoblja. Povelja proklamira vrijednosti i rješenja za budućnost koja uzimaju u obzir postojeće stanje, okolišne i društveno kulturne aspekte te odražavaju i prenose vrijednosti kreativnog duha, kulturne posebnosti i različitost populacije koja tamo živi [6]. Buduće uređenje Trga Vatroslava Lisinskog trebalo bi odražavati ove temeljne postavke.

Zbog svojih prostornih karakteristika, Trg ima potencijal da uz postojeća dva trga u Tvrđi (Trg Sv. Trojstva profani trg i Trg J. Križanića - sakralni trg) postane treći trg u sustavu tvrđavskih trgova i tako kompletira cjelinu javnih parternih površina Tvrđe. Za razliku od navedena dva uređena trga koja su po svim obodima zatvoreni prostori, Trg Vatroslava Lisinskog je poluotvoreni jer se u zapadnom dijelu otvara prema Dravi i vizurama na lijevu obalu. 


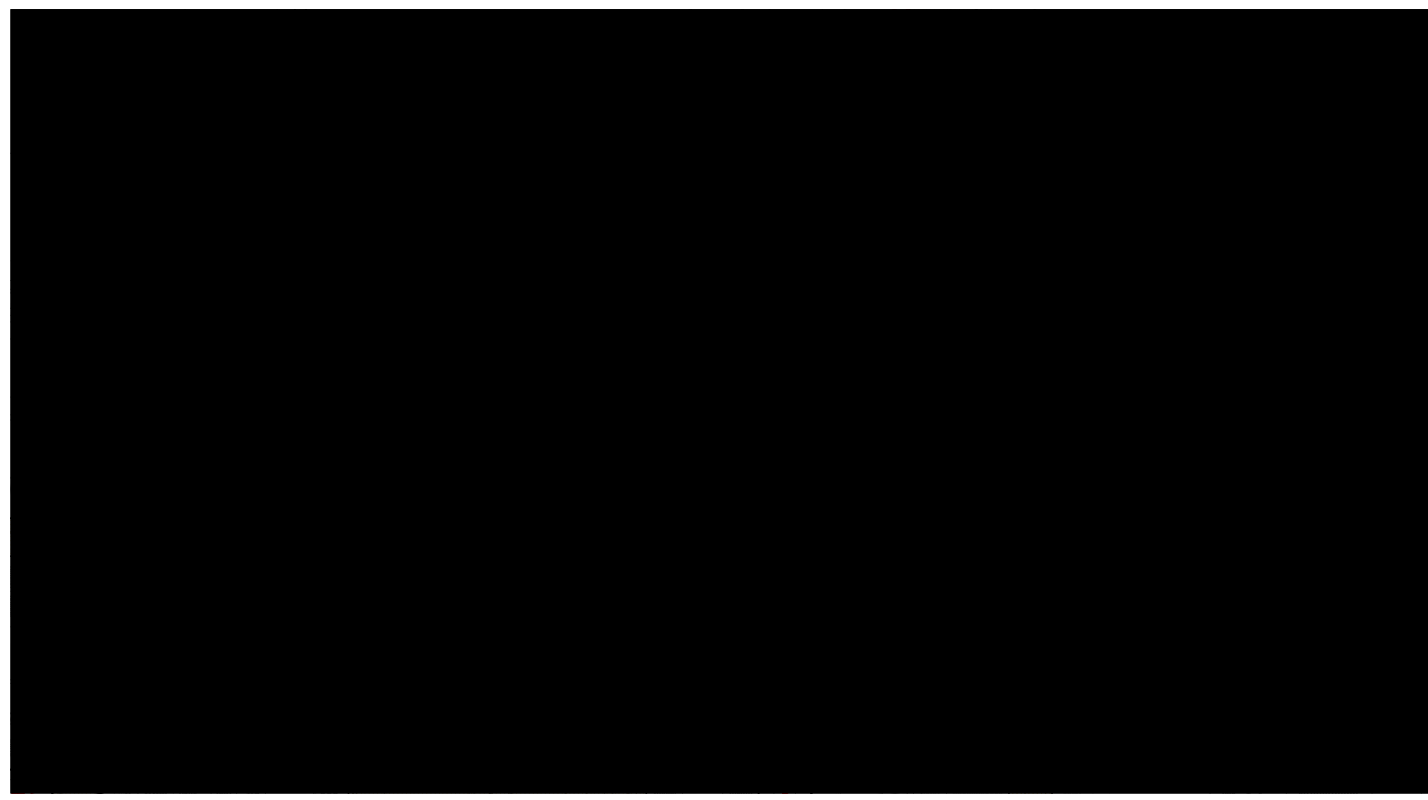

\section{Slika 10 - Karta 2.1. Promet, Urbanistički plan uređenja osječke Tvrđe}

Urbanistički potencijal prostora Trga Vatroslava Lisinskog ogleda se u:

- nepostojanju identiteta i simbolike: novi identitet prostora može se stvoriti uređenjem

- njegovoj veličini i mjestu u strukturi Trrđe u sjevernom dijelu, u blizini rijeke Drave

- ambijentalnoj vrijednosti obodnih zgrada koje većinom imaju stilska obilježja baroka

- namjeni obodnih sadržaja (Rektorat, Franjevački samostan s crkvom, budući hostel u zgradi bivše pekarne, Centar za rehabilitaciju) koji imaju različite režime korištenja

- ukidanju kolnog prometa s plohe Trga i njegovom pretvaranju u pješačku površinu, jer bi na taj način Trg bio integriran u sustav pješačkih javnih prometnica Tvrđe

- glavnoj pješačkoj prometnici prema Dravi koja prolazi zapadnim rubom Trga.

Socijalni potencijal Trga kao javnog prostora okupljanja i zadržavanja je u:

- privlačenju raznih kategorija korisnika u svakodnevnom životu (Rektorat - studenti i nastavnici, hostelstudenti, Frajnevački samostan-svećenstvo, Franjevačka crkva-svećenstvo i građanstvo)

- integriranju u ostale javne prostore Tvrđe na kojima se odvijaju povremene javne manifestacije (sajmovi, Osječko ljeto kulture i sl.)

- percipiranju identiteta grada: $16 \%$ stanovnika Osijeka navodi Tvrđu kao prvu asocijaciju identiteta grada, u nešto manjoj mjeri (manje od 10\%) Tvrđa je prva asocijacija za stanovnike drugih hrvatskih gradova (Dubrovnik, Rijeka, Varaždin) [7]

- percipiranju prezentiranja grada: $86 \%$ stanovnika Osijeka navodi Osječko ljeto kulture koje se održava u Tvrđi kao formu kroz koju se Osijek prezentira [7].

\section{Zaključak}

Kroz članak je prikazan povijesni i prostorni nastanak te razvitak prostora Trga Vatroslava Lisinskog u osječkoj Tvrđi. Od početka izgradnje Tvrđe, Trg Vatroslava Lisinskog formirao se kao neizgrađeni prostor u njezinom sjevernom dijelu. Geneza razvoja prostora Trga može se pratiti kroz arhivske karte i literaturu iz kojih je vidljivo da Trg nije imao jasno definiranu namjenu te da se planiranjem drvoreda i šetališta pokušala afirmirati njegova ambijentalna vrijednost. Trg Vatroslava Lisinskog u Tvrđi danas je prostor bez identiteta, bez definiranih prostornih i oblikovnih obilježja i u javnom životu Tvrđe ne igra bitnu ulogu. 
Činjenica da Trg nikada nije bio u potpunosti funkcionalno i oblikovno definiran daje mogućnost da se njegove urbanističke i arhitektonske vrijednosti afirmiraju u budućem uređenju te da se Trgu odredi jasan oblikovni i društveni identitet.

\section{Literatura}

[1] Pinterović, D. 1981: Mursa, romantizatorsko središte slavonskog i baranjskog dijela Panonije Inferior, Osijek kao polarizacijsko žarište, JAZU, Centar za znanstveni rad Osijek, Osijek, pp 73-87

[2] Krajnik, D.: Obad-Šćitaroci, M. 2008: Preobrazba bastionskih utvrđenja Osijeka, Prostor, 16[2008], 2[36], pp 169-179

[3] Mažuran, I. 1994: Srednjevjekovni i turski Osijek, HAZU, Zavod za znastveni rad u Osijeku, Osijek

[4] Sršan, S. 2001: Ulice i trgovi grada Osijeka“, Državni arhiv u Osijeku, Osijek

[5] ICOMOS, 1976: International Recommendation concerning the Safeguarding and Contemporary Role of Historic Areas, www.icomos.org/charters/towns_e.pdf

[6] ICOMOS, 1987: Charter for the Conservation of Historic Towns and Urban Areas, www.icomos.org/charters/towns_e.pdf

[7] Kamenov, Ž. 2008: Istraživanje identiteta grada Osijeka, Filozofski fakultet u Zagrebu, Zagreb

\section{Izvori ilustracija}

- Slika 1 - Trg Vatroslava Lisinskog danas (izvor: arhiva autorica)

- Slika 2 - Pokusna arheološka istraživanja na Trgu Vatroslava Lisinskog, 2010. do 2011. godine (izvor: http://arheoloskimuzejosijek.hr/?p=829, 20. travnja 2013. godine, 15.45 sati)

- Slika 3 - Rektifikacija plana turskog Osijeka iz 1688. godine (izvor: Urbanističko - konzervatorska studija prostora bastione trase i vanjskih utvrđenja Tvrđe, Povijesni razvitak i valorizacija bastione trase baroknog grada-tvrđave, osječke Tvrđe, Studio X, 2009., 25. travnja 2013. godine, 11.50 sati)

- Slika 4 - Dio karte Tvrđe iz 1811. godine koji prikazuje položaj i naziv Trga Vatroslava Lisinskog u sjevernom dijelu Tvrđe - Platz des abgebrenten Proviant Magazins (izvor: Državni arhiv u Osijeku)

- Slika 5 - Dio karte Tvrđe iz 1844. godine s jednostrukim, nepravilnim drvoredom na Trgu Vatroslava Lisinskog (izvor: Državni arhiv u Osijeku)

- Slika 6 - Dio karte Tvrđe iz 1861. godine s dvostrukim drvoredom na Trgu Vatroslava Lisinskog (izvor: Državni arhiv u Osijeku)

- $\quad$ Slika 7 - Regulatorna osnova 1912. godine (izvor: Državni arhiv u Osijeku)

- Slika 8 - Dio karte Tvrđe Dio karte Tvrđe s kraja tridesetih godina 20. stoljeća s prikazom tri katastarske čestice na Trgu Vatroslava Lisinskog (izvor: Državni arhiv u Osijeku)

- Slika 9 - Dio karte Osijeka iz 1945. godine (izvor: Državni arhiv u Osijeku)

- Slika 10 - Karta 2.1. Promet, Urbanistički plan uređenja osječke Tvrđe (izvor: Službeni glasnik" Grada Osijeka broj 16/11, www.osijek.hr, 21. travnja 2013. godine, 10.15 sati) 